\author{
CTPАТЕГIЧНI \\ НАПРЯМИ \\ РОЗВИТКУ \\ ВИРОБНИЦТВА \\ БІОПАЛИВ ІЗ \\ АГРОБІОМАСИ \\ СІЛЬСЬКО- \\ ГОСПОДАРСЬКИХ \\ ПІДПРИЕМСТВ \\ УКРАЇНИ
}

\author{
ТОКАРЧУК Д.М., \\ кандидат економічних наук, \\ доцент кафедри адміністративного \\ менеджменту та альтернативних джерел енергії, \\ Вінницький національний аграрний університет \\ (м. Вінниця)
}

У статті обтрунтовано, щуо аграрний сектор Украӥни має значний біоенергетичний потенціал. Першою складовою иьього потенціалу $\epsilon$ сільськогосподарські культури: традииійні (зернові, иукрові буряки, соняшник, ріпак та ін.), які можна використати для виробництва біоетанолу, біодизелю та енергетичні (верба, тополя, міскантус), які використовуються для виробництвв твердих біопалив або біопалив другого покоління. Другою складовою є органічні відходи рослинництва $і$ тваринництва, які є потениійною сировиною для виробництва біогазу та твердих біопалив.

Запропоновано алгоритм розробки та реалізації стратегії розвитку виробництва біопалив із біоенергетичного потенціалу агробіомаси сільськогосподарських підприємств із акцентом на обов'язковості постійного ї̈ моніторингу та коригуванні для досягнення запланованих показників. Обтрунтовано доцільність застосування методики SWOT-аналізу при розробиі означеної стратегіï.

Проаналізовано сильні та слабкі сторони аграрних підприємств із точки зору розвитку біоенергетики. Для иього оцінено їх прибутковість і рентабельність, динаміку вирощування сільськогосподарських культур, які можна використати для виробництва біопалив, обсяги утворення органічних відходів. Серед основних сильних сторін - наявність потужного біоенергетичного потенціалу, слабких - опір змінам та небажання керівників ризикувати, вкладаючи значні кошти у виробництво біопалив. Аналіз зовнішнього середовища показав наявність як сприятливих (співпраця з міжнародними фінансовими організаціями, збільшення попиту на біоенергетичну сировину тощо), так і несприятливих факторів розвитку біоенергетичного потенціалу (висока вартість обладнання для біовиробнищтва, несприятлива кредитна політика тощо).

Поєднання сильних та слабких сторін внутрішнього середовища, а також можливостей $i$ загроз зовнішнього середовища сільськогосподарських підприємств у біоенергетиці, дало змогу виділити чотири потенційні стратегічні напрями використання біоенергетичного потениіалу агробіомаси: організаџія підприємствами виробництва всіх видів біопалив (рідкі, тверді, газоподібні), енергетична автономізачія; підвищення біоенергетичного потенціалу інтенсивним шляхом, організація виробництва тих видів біопалив, для яких біоенергетичний потенціал є найбільщим; нарощування біоенергетичного потенціалу екстенсивним шляхом, реалізація біоенергетичних культур вітчизняним виробникам біопалив; підприємства не нарощують біоенергетичний потенціал, залишаються виробниками лише тих сільськогосподарських культур, на які є попит на вітчизняному і світовому ринках.

Ключові слова: біоенергетичний потенціал, стратегія, органічні відходи, біопаливо, біоенергетика, енергетична автономізація.

Табл.: 5. Рис.: 2. Літ.: 14. 


\title{
STRATEGIC DIRECTIONS OF DEVELOPMENT OF BIOLFUELS PRODUCTION FROM AGROBIOMASS OF AGRICULTURAL ENTERPRISES OF UKRAINE
}

\author{
TOKARCHUK Dina, \\ Candidate of Economic Sciences, Associate Professor \\ of the Department of Administrative \\ Management and Alternative Energy Sources, \\ Vinnytsia National Agrarian University \\ (Vinnytsia)
}

\begin{abstract}
The article substantiates that the agricultural sector of Ukraine has a significant bioenergy potential. The first component of this potential is agricultural crops: traditional (cereals, sugar beets, sunflowers, rapeseed, etc.), which can be used for the production of bioethanol, biodiesel and energy crops (willow, poplar, miscanthus), which are used for the production of solid biofuels or second generation biofuels. The second component is organic waste from crops and livestock, which is a potential raw material for the production of biogas and solid biofuels.

An algorithm for the development and implementation of a strategy for the development of biofuel production from the bioenergy potential of agrobiomass of agrarian enterprises has been offered with an emphasis on the obligation of its constant monitoring and correction to achieve the planned indicators. The expediency of using the SWOT-analysis methodology in the development of this strategy has been substantiated.

The strengths and weaknesses of agricultural enterprises have been analyzed from the point of view of bioenergy development. For this, there were assessed their profitability and efficiency, the dynamics of growing of agricultural crops that can be used for the production of biofuel, and the volume of organic waste generated. Among the main strengths are strong bioenergy potential, weaknesses are resistance to change and the reluctance of managers to take risks by investing a lot in biofuel production. Analysis of the external environment showed the presence of both favorable (cooperation with international financial organizations, an increase in demand for bioenergy raw materials) and unfavorable factors for the development of bioenergy potential (high cost of equipment for bio-production, unfavorable credit policy, etc.).

The combination of the strengths and weaknesses of the internal environment, as well as the opportunities and threats of the external environment of agricultural enterprises in bioenergy made it possible to identify four potential strategic directions for the development of using bioenergy potential of agrobiomass: organization of the production of all types of biofuels (liquid, solid, gaseous) by enterprises, energy autonomy; increasing of bioenergy potential in an intensive way, organizing the production of those types of biofuels for which bioenergy potential is the largest; building up bioenergy potential in an extensive way, selling bioenergy crops to Ukrainian biofuel producers; enterprises do not increase their bioenergy potential, they remain producers of only those agricultural crops for which there is a demand in Ukrainian and the world markets.
\end{abstract}

Key words: bioenergy potential, strategy, organic waste, biofuel, bioenergy, energy autonomy.

Table: 5. Fig.: 2. Ref .: 14 .

\author{
СТРАТЕГИЧЕСКИЕ НАПРАВЛЕНИЯ РАЗВИТИЯ \\ ПРОИЗВОДСТВА БИОТОПЛИВ ИЗ АГРОБИОМАСЫ \\ СЕЛЬСКОХОЗЯЙСТВЕННЫХ ПРЕДПРИЯТИЙ УКРАИНЫ
}



административного менеджмента и альтернативных источников энергии, Винницкий национальный аграрный университет (2. Винница)

В статье обосновано, что аграрный сектор Украины имеет значительный биоэнергетический потенциал. Первой составляющей этого потенциала являются сельскохозяйственные культуры: традииионные (зерновые, сахарная свекла, подсолнечник, paпс и др.), которые можно использовать для производства биоэтанола, биодизеля $и$ энергетические (ива, тополь, мискантус), которые используются при производстве твердых биотоплив и биотоплив второго поколения. Второй составляющей являются органические отходы растениеводства и животноводства, являющиеся потенциальным сырьем для производства биогаза и твердых биотоплив.

Предложен алгоритм разработки и реализачии стратегии развития производства биотиплив из биоэнергетического потенциала агробиомассы сельскохозяйственных предприятий с акиентом на обязательности постоянного ее мониторинга и коррекиии для достижения запланированных показателей. Обоснована иелесообразность применения методики SWOT-анализа при разработке указанной стратегии.

Проанализированы сильные и слабые сторонь аграрных предприятий с точки зрения развития биоэнергетики. Для этого оценена их прибыльность и рентабельность, динамика выращивания культур, которые можно использовать для производства биотоплив, объемь образования органических отходов. Среди основных сильных сторон - наличие мощного биоэнергетического потенциала, слабых - сопротивление изменениям и нежелание руководителей рисковать, вкладывая значительные средства в производство биотоплив. Анализ внешней среды показал наличие как благоприятных (сотрудничество $c$ международными финансовыми организациями, увеличение спроса на биоэнергетическое сырье), так и неблагоприятных факторов развития биоэнергетического потенциала (высокая стоимость оборудования для биопроизводства, неблагоприятная кредитная политика и т.д.).

Сочетание сильных и слабых сторон внутренней среды, а также возможностей и угроз внешней среды сельскохозяйственных предприятий в биоэнергетике позволило выделить четыре потенциальные стратегические направления использования биоэнергетического потенциала агробиомассы: организаџия предприятиями производства всех видов биотоплив (жидкие, твердые, газообразные), энергетическая автономизаиия; увеличение биоэнергетического потенциала интенсивным путем, организация производства тех видов биотоплив, для которых биоэнергетический потенщиал является крупнейшим; наращивание биоэнергетического потенцииала экстенсивным путем, реализация биоэнергетических культур отечественным производителям биотоплив; предприятия не наращиивают биоэнергетический потенциал, остаются производителями только тех сельскохозяйственных культур, на которые есть спрос на отечественном и мировом рынках.

Ключевые слова: биоэнергетический потенциал, стратегия, органические отходы, биотопливо, биоэнергетика, энергетическая автономизация.

Табл.: 5. Рис.: 2. Лит.: 14.

Постановка проблеми. Сьогодні актуальними проблемами економіки $\epsilon$ зростання поточних витрат виробництва й значні витрати на енергоресурси, формування сприятливого економічного клімату щодо подальшого розвитку паливно-енергетичного комплексу, розробка світовим співтовариством дієвих 
методів регулювання та узгодженої стратегії розвитку світової енергетики. Проблематика ощадного використання енергоносіїв характеризується значною багатоплановістю і $є$ необхідним стратегічним напрямом ефективного використання виробничих потужностей iз оптимальними енергетичними витратами. При цьому покращення рівня життя населення та його соціальноекономічного стану багато в чому залежатиме від раціонального використання енергоносіїв та природо-ресурсного потенціалу, що на сучасному етапі господарювання набуває особливої актуальності [1, с. 6].

Нині активно розвивається альтернативна енергетика у більшості країн світу: сонячна, вітрова, геотермальна, малих річок, енергії біомаси. Особливої уваги заслуговують напрями використання біоенергетичного потенціалу агробіомаси, оскільки це дасть змогу країнам відмовитися повністю або частково від традиційних енергоресурсів та забезпечити власні енергетичні потреби.

Використання біоенергетичних ресурсів дає змогу зменшити антропогенний вплив на довкілля, зменшити енергетичну залежність України, використати місцеві ресурси, зменшити рівень безробіття, збільшити податкові надходження, покращити якість надання послуг із тепло- та гарячого водопостачання, поліпшити торгівельно-платіжний баланс країни. Саме тому розвиток сфери біоенергетики є одним із актуальних напрямків відновлюваної енергетики в Україні, а існуючі потужності агропромислового комплексу та наявні трудові ресурси України сприяють розвитку цього напряму [7, с. 29].

Існуючі потужності АПК нашої держави обумовлюють значний потенціал виробництва біопалив [2, с. 41], для нарощування якого необхідно запровадити раціональні сівозміни з метою вирощування енергетичних культур заради невиснажливого використання грунтів [14, c. 173]; використання біоенергетичного потенціалу органічних відходів рослинництва і тваринництва [12, c. $289 ; 13$, c. 139$]$.

Аналіз останніх досліджень та публікацій. Дослідженням розвитку біоенергетичного потенціалу присвячена чимала кількість праць науковців. Фундаментальний вклад у дослідження розвитку біоенергетики в Україні зробили д.е.н., професор, академік НААНУ Калетнік Г.М. [3; 8] та д.е.н., професор Гончарук I.В. [1]. Серед вітчизняних науковців, які займаються означеною тематикою, слід згадати Гелетуху Г.Г. [5], Ємчик Т.В. (Гончарук Т.В.) [2], Ігнатенка О.П. [7], Семчук І.А. [4], Паламаренко Я.В. [10], Пришляк Н.В. [11], Фурман I.В. [14] та ін.

Незважаючи на значні напрацювання науковців, сьогодні актуальним питанням залишається комплексний аналіз біоенергетичного потенціалу сільськогосподарських культур та органічних відходів для забезпечення стратегічних напрямів виробництва біопалив на рівні аграрних підприємств із метою їх енергетичної автономізації.

Формулювання цілей статті. Метою наукового дослідження є аналіз потенціалу виробництва біопалив сільськогосподарськими підприємствами 
України з агробіомаси на тривалу перспективу.

Виклад основного матеріалу дослідження. Потенціал виробництва енергії з біомаси агропромислового комплексу України є одним із найбільших у світі, що дозволяє сільськогосподарським підприємствам розвивати свої стратегічні напрями впровадження біоенергетики в їх діяльність, а також ініціювати створення з цією метою відповідного інвестиційного ринку. Перехід енергетичної системи аграрних формувань на відновлювані джерела енергії стає все більш ймовірним, оскільки їхні витрати на імплементацію технологій знижуються, а ціни на нафту і газ продовжують значно коливатись і зростають. Використання біопалив та біоенергії сільськогосподарськими підприємствами сприятиме забезпеченню стійкого енергопостачання, допоможе зменшити локальні та глобальні атмосферні викиди і забезпечить комерційно привабливі варіанти для задоволення конкретних потреб у автономному енергопостачанні аграрного сектору України за рахунок біомаси.

Процес розробки та реалізації стратегії розвитку виробництва біопалив із біоенергетичного потенціалу агробіомаси сільськогосподарських підприємств України відображено на рис. 1.

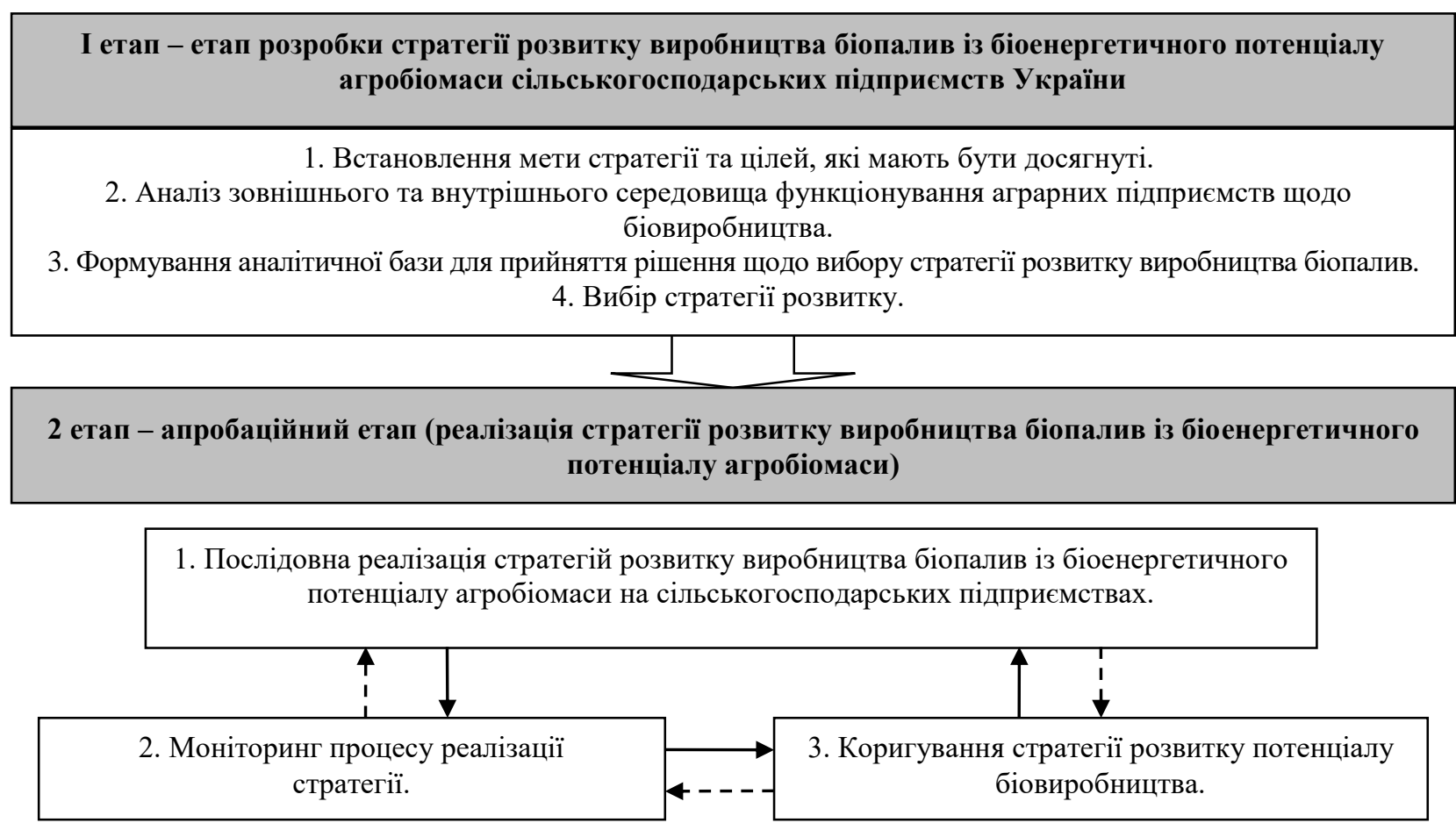

\section{Рис. 1. Алгоритм розробки та реалізації стратегії розвитку виробництва біопалив із біоенергетичного потенціалу сільськогосподарських культур та органічних відходів аграрних підприсмств \\ Джерело: розроблено автором}

Перший етап передбачає встановлення мети та цілей, які мають бути досягнуті. Мета стратегії розвитку виробництва біопалив із біоенергетичного потенціалу агробіомаси сільськогосподарських підприємств - зменшення енергозалежності та зростання прибутковості діяльності, завдяки використанню 
біоенергетичного потенціалу для виробництва біопалив та біоенергії для подальшого забезпечення енергетичної автономії підприємств.

Мета стратегії передбачає досягнення наступних цілей:

1) нарощування біоенергетичного потенціалу;

2) організація виробництва біопалив із наявних біоенергетичних ресурсів;

3) заміна біопаливом традиційних енергоресурсів, які постійно зростають у вартості, та зменшення, завдяки цьому, собівартості виробництва сільськогосподарської продукції;

4) реалізація надлишку біопалив та біоенергії на ринку.

Для якісної розробки стратегії розвитку виробництва біопалив із біоенергетичного потенціалу агробіомаси сільськогосподарських підприємств необхідним є проведення SWOT-аналізу для визначення можливих варіантів стратегічного розвитку.

Застосування методу SWOT-аналізу широко розповсюджено, оскільки дозволяє встановити зв'язок між внутрішнім середовищем підприємств та зовнішнім оточенням. Таким чином, при плануванні заходів для напрямів використання біоенергетичного потенціалу аграрних підприємств необхідно поєднувати внутрішні можливості (іх сильні та слабкі сторони) і зовнішню ситуацію у державі, що відображається у можливостях і загрозах.

Успішне застосування методології SWOT-аналізу допомагає структурувати наявну інформацію, по-новому поглянути на поточну ситуацію і не лише оцінити можливості, розкрити загрози, але і спробувати, на підставі цього, врахувати отриману інформацію у майбутніх стратегіях розвитку підприємства [9, с. 508].

Результати SWOT-аналізу передбачають розробку конкретних матриць, які відображають ймовірні вектори стратегічного розвитку виробництва біопалив із біоенергетичного потенціалу агробіомаси сільськогосподарських підприємств України.

Основною метою SWOT-аналізу діяльності аграрних підприємств щодо розвитку виробництва біопалив із біоенергетичного потенціалу сільськогосподарських культур та органічних відходів $\epsilon$ виявлення конкурентних переваг на основі діагностики бізнес-процесів та визначення основних перспективних шляхів розвитку підприємств у рамках конкретної ринкової ситуації.

Внутрішнє середовище аграрних підприємств відрізняється залежно від спеціалізації, розміру, забезпеченості ресурсами, розвитку маркетингової діяльності тощо. Але $є$ типові риси, притаманні більшості підприємств у сфері біоенергетики.

Зокрема, за досліджуваний період (2015-2019рр.) більшість сільськогосподарських підприємств України характеризуються прибутковістю (83,4-88,9\%), рівень рентабельності всієї діяльності знаходився в діапазоні 14,2$30,6 \%$ (табл. 1). 
Таблиия 1

\section{Основні фінансові показники діяльності сільськогосподарських} підприсмств України, 2015-2019 рр.

\begin{tabular}{|l|c|c|c|c|c|c|}
\hline \multirow{2}{*}{ Показники } & \multicolumn{5}{|c|}{ Роки } & \multicolumn{1}{c|}{$\begin{array}{c}\text { Відхилення } \\
\text { 2019 р. до } \\
2015 \text { р. (+,-) }\end{array}$} \\
\cline { 2 - 8 } & 2015 & 2016 & 2017 & 2018 & 2019 & \\
\hline Чистий прибуток (збиток), млн грн. & 101912,2 & 89816,3 & 68579,8 & 90970,8 & 90167,0 & $-11745,2$ \\
\hline $\begin{array}{l}\text { Підприсмства, які одержали чистий } \\
\text { прибуток: }\end{array}$ & & & & & & \\
\hline - у відсотках до загальної кількості & 88,9 & 88,4 & 86,7 & 86,7 & 83,4 & $-5,5$ в.п. \\
\hline - фінансовий результат, млн грн. & 127525,5 & 102496,1 & 88979,3 & 93249 & 114666,4 & $-12859,1$ \\
\hline $\begin{array}{l}\text { Підприсмства, які одержали чистий } \\
\text { збиток: }\end{array}$ & & & & & \\
\hline - у відсотках до загальної кількості & 11,1 & 11,6 & 13,3 & 13,3 & 16,6 & 5,5 в.п. \\
\hline - фінансовий результат, млн грн. & 25613,3 & 12679,8 & 20399,5 & 2278,2 & 24499,4 & $-1113,9$ \\
\hline Рівень рентабельності всісї діяльності, \% & 30,4 & 25,6 & 16,5 & 14,2 & 16,1 & $-14,3$ в.п. \\
\hline
\end{tabular}
Джерело: розраховано автором за даними [6]

Таким чином, можемо зробити висновок про те, що більшість із цих підприємств мають кошти, які можна інвестувати у біоенергетичні проєкти. Проте, на практиці такі проєкти є досить дорогими; більш рентабельним є широкомасштабне виробництво біопалив, яке потребує кооперації декількох підприємств, що досить важко реалізувати.

Збитковою або малорентабельною залишається галузь тваринництва (табл. 2), яка продукує потенційну сировину для виробництва біогазу - гній тварин та пташиний послід, - що ускладнює організацію виробництва цього виду біопалив.

Таблиия 2

Рентабельність виробництва продукції тваринництва у сільськогосподарських підприсмствах України, 2015-2019 рр., \%

\begin{tabular}{|l|c|c|c|c|c|c|}
\hline \multirow{2}{*}{\multicolumn{1}{|c|}{ Продукція тваринництва }} & \multicolumn{5}{|c|}{ Роки } & Відхилення 2019 р. \\
\cline { 2 - 6 } & 2015 & 2016 & 2017 & 2018 & 2019 & до 2015 р. (+,-) \\
\hline Велика рогата худоба на м'ясо & $-16,9$ & $-23,2$ & 3,4 & $-17,7$ & $-27,1$ & $-10,2$ в.п \\
\hline Свині на м'ясо & 12,6 & $-4,1$ & 3,5 & 6,9 & 4,7 & $-7,9$ в.п. \\
\hline Вівці та кози на м'ясо & $-26,6$ & $-31,5$ & $-39,6$ & $-16,6$ & $-39,7$ & $-13,1$ в.п. \\
\hline Птиця на м'ясо & $-5,4$ & 3,4 & 7 & 5,7 & $-3,7$ & 1,7 в.п. \\
\hline Молоко & 12,7 & 18,6 & 26,9 & 16,1 & 20,6 & 7,9 в.п. \\
\hline Яйця & 60,9 & 0,5 & -9 & 5,4 & $-23,5$ & $-84,4$ в.п. \\
\hline Вовна & $-61,9$ & $-31,8$ & $-69,8$ & $-69,5$ & $-71,1$ & $-9,2$ в.п. \\
\hline
\end{tabular}

Джерело: розраховано автором за даними [6]

Власне потенціал біоенергетичних культур і відходів сільськогосподарських підприємств $\epsilon$ досить значним. Традиційно до біоенергетичних культур належать ті культури, які можна використати на виробництво біоетанолу першого покоління (цукрові буряки, зернові, в т.ч. кукурудза на зерно тощо), біодизелю (ріпак, соняшник, соя), твердих біопалив (енергетична верба, тополя, міскантус, світчграс), біогазу (переважно кукурудза на силос).

Аналіз динаміки вирощування основних сільськогосподарських культур (табл. 3) показує, що їх виробляють у достатній кількості і без загрози 
продовольчій безпеці ми можемо використовувати значні обсяги потенційної біоенергетичної сировини на виробництво біоетанолу та біодизелю.

Таблиия 3

Валові збори основних культур, вирощених у сільськогосподарських підприємствах України, що с сировиною для виробництва біопалив першого покоління, 2015-2019 рр., тис. т

\begin{tabular}{|l|c|c|c|c|c|c|}
\hline \multirow{2}{*}{$\begin{array}{c}\text { Сільськогосподарські } \\
\text { культури }\end{array}$} & \multicolumn{5}{|c|}{ Роки } & Відхилення 2019 p. \\
\cline { 2 - 7 } & 2015 & 2016 & 2017 & 2018 & 2019 & 2015 р. (+,-) \\
\hline $\begin{array}{l}\text { Культури зернові } \\
\text { зернобобові }\end{array}$ & 465065,8 & 52022,2 & 479050,9 & 560961,9 & 599820,8 & 134755,0 \\
\hline в т.ч. кукурудза на зерно & 189691,8 & 23318,6 & 203887,0 & 307060,6 & 306644,1 & 116952,3 \\
\hline Буряки цукрові & 95537,6 & 13348,9 & 142271,8 & 133166,3 & 96583,1 & 1045,5 \\
\hline Соняшник & 95492,5 & 11730,1 & 105967,3 & 121935,8 & 130886,5 & 35394,0 \\
\hline Соя & 36750,4 & 3999,5 & 36471,3 & 41020,8 & 33384,0 & $-3366,4$ \\
\hline Ріпак і кольза & 17092,6 & 1123,1 & 21610,5 & 27208,8 & 32478,5 & 15385,9 \\
\hline
\end{tabular}

Джерело: розраховано автором за даними [6]

Окрему увагу слід приділити відходам рослинництва і тваринництва, що утворюються в значних обсягах у сільськогосподарських підприємствах України (табл. 4). Їх можна використати для виробництва твердих біопалив (брикети, пелети) та біогазу. Проте, необхідно пам'ятати про необхідність використання певної їх частини в якості добрив для збереження родючості грунтів в умовах, коли мінеральні добрива зростають у ціні й не кожне підприємство у змозі їх купувати в достатній кількості. Що стосується практики запровадження проєктів із виробництва біопалив аграрними підприємствами, то слід зазначити, що, на жаль, вони є поодинокими.

Таблиця 4

Обсяги утворення основних органічних відходів рослинництва i тваринництва в сільськогосподарських підприємствах України, 2015-2019 рр., тис. т

\begin{tabular}{|c|c|c|c|c|c|c|}
\hline \multirow{2}{*}{ Вид відходів } & \multicolumn{5}{|c|}{ Роки } & \multirow{2}{*}{$\begin{array}{c}\text { Відхилення } 2019 \text { р. } \\
\text { до } 2015 \text { р. }(+,-)\end{array}$} \\
\hline & 2015 & 2016 & 2017 & 2018 & 2019 & \\
\hline \multicolumn{7}{|c|}{ Відходи рослинництва: } \\
\hline зернових культур (солома) & 275374,0 & 28703,6 & 275163,9 & 253901,3 & 293176,7 & 17802,7 \\
\hline кукурудзи на зерно (стебла) & 246599,3 & 30314,1 & 265053,1 & 399178,8 & 398637,3 & 152038,0 \\
\hline буряків цукрових (гичка) & 47768,8 & 6674,5 & 71135,9 & 66583,2 & 48291,6 & 522,8 \\
\hline соняшнику (стебла) & 181435,8 & 22287,2 & 201337,9 & 231678,0 & 248684,4 & 67248,6 \\
\hline сої (солома) & 33075,4 & 3599,6 & 32824,2 & 36918,7 & 30045,6 & $-3029,8$ \\
\hline ріпаку і кользи (солома) & 34185,2 & 2246,2 & 43221,0 & 54417,6 & 64957,0 & 30771,8 \\
\hline \multicolumn{7}{|c|}{ Відходи тваринництва: } \\
\hline гній ВРХ & 12961,0 & 12383,6 & 11901,0 & 11610,3 & 10706,4 & $-2254,5$ \\
\hline гній свиней & 13332,9 & 12835,8 & 11891,6 & 12222,8 & 11879,0 & $-1453,9$ \\
\hline гній кіз та овець & 205,5 & 205,9 & 205,7 & 200,5 & 185,4 & $-20,1$ \\
\hline гній коней & 154,4 & 140,6 & 123,8 & 103,4 & 90,3 & $-64,1$ \\
\hline пташиний послід & 6162,5 & 6042,2 & 6190,2 & 6536,9 & 7029,9 & 867,3 \\
\hline
\end{tabular}

Джерело: розраховано автором за даними [6]

У межах виконання наукової роботи молодих учених за рахунок загального фонду державного бюджету «Розробка новітньої концепції використання відходів сільського господарства для забезпечення енергетичної 
автономії аграрних підприємств» (0119U100786) було зроблено анкетування керівників сільськогосподарських підприємств щодо потенціалу, обізнаності та перспектив запровадження біовиробництва. На жаль, більшість керівників показали неготовність до виробництва біопалив, не дивлячись на обізнаність щодо переваг цього виду діяльності [4, с. 1641].

3 погляду розвитку біоенергетичного потенціалу аграрних підприємств i його використання у біовиробництві існують об'єктивні зовнішні фактори сприяння (можливе розширення ринків збуту, зростання кількості підприємств, що вироблятимуть біопалива i формуватимуть попит на біоенергетичні культури, вдосконалення державної підтримки тощо) та гальмування цього процесу (висока вартість обладнання для виробництва біопалив, нестабільний попит на біопаливо, несприятлива кредитна політика i т.д.). Відповідно аграрним підприємствам необхідно таким чином вибудовувати стратегії розвитку виробництва біопалив із біоенергетичного потенціалу агробіомаси, щоб максимально використати можливості зовнішнього середовища та мінімізувати вплив загроз.

Результатом проведеного аналізу $\epsilon$ формування основних загроз та можливостей зовнішнього середовища, а також сильних та слабких сторін діяльності сільськогосподарських підприємств України у сфері біоенергетики (табл. 5).

Таблиия 5

Основні загрози та можливості зовнішнього середовища, а також сильні та слабкі сторони діяльності сільськогосподарських підприсмств України у сфері біоенергетики

\begin{tabular}{|c|c|}
\hline Зовнішнє середовище & Внутрішнє середовище \\
\hline Можливості & Сильні сторони \\
\hline $\begin{array}{l}\text { 1. Вдосконалення державної підтримки виробництва } \\
\text { біопалив сільськогосподарськими підприємствами } \\
\text { (субсидій, дотації). } \\
\text { 2. Наявність науково-дослідних установ та ЗВО, які } \\
\text { займаються питанням біовиробництва (від селекції сортів } \\
\text { та гібридів біоенергетичних культур до бізнес-планування } \\
\text { організації виробництва біопалив під ключ). } \\
\text { 3. Співпраця з міжнародними фінансовими організаціями, } \\
\text { що кредитують проєкти з виробництва біопалив в Україні. } \\
\text { 4. Зростання кількості підприємств, що вироблятимуть } \\
\text { біопаливо і формуватимуть попит на біоенергетичні } \\
\text { культури. } \\
\text { 5. Агрострахування біоенергетичних культур на випадок } \\
\text { неврожаю. }\end{array}$ & $\begin{array}{c}\text { 1. Наявність потенціалу енергетичних культур для } \\
\text { біовиробництва. } \\
\text { 2. Наявність біоенергетичного потенціалу } \\
\text { органічних відходів рослинництва та тваринництва. } \\
\text { 3. Прибутковість більшості сільськогосподарських } \\
\text { підприємств (наявність коштів для } \\
\text { повного/часткового фінансування біоенергетичних } \\
\text { проєкті). } \\
\text { 4. Досвід вирощування енергетичних культур для } \\
\text { виробництва біопалив першого покоління (зернові, } \\
\text { цукрові буряки, ріпак тощо). } \\
\text { 5. Сприятливі грунтово-кліматичні умови для } \\
\text { розвитку сировинної бази виробництва біопалив. }\end{array}$ \\
\hline Загрози & Слабкі сторони \\
\hline $\begin{array}{c}\text { 1. Відсутність стратегії розвитку виробництва біопалив на } \\
\text { загальнодержавному рівні, нестабільний попит на } \\
\text { біопаливо. } \\
\text { 2. Проблеми із забезпеченням вітчизняних виробників } \\
\text { біопалив сировиною через значний ії експорт. } \\
\text { 3. Висока вартість обладнання для виробництва біопалив. } \\
\text { 4. Несприятлива кредитна політика вітчизняних } \\
\text { банківських установ. } \\
\text { 5. Підвищення світових та європейських стандартів на } \\
\text { біопаливо, що ускладнює доступ на зовнішні ринки } \\
\text { української біоенергетичної продукції. }\end{array}$ & $\begin{array}{c}\text { 1. Переважання застарілих методів поводження з } \\
\text { відходами рослинництва та побічною продукцією } \\
\text { тваринництва (гноєм) та опір змінам. } \\
\text { 2. Відсутність досвіду в організації виробництва } \\
\text { біопалив. } \\
\text { 3. Відсутність або недостатній розвиток } \\
\text { інноваційної складової у господарській діяльності. } \\
\text { 4. Збитковість або низька рентабельність галузі } \\
\text { тваринництва, що ускладнює організацію } \\
\text { виробництва біогазу з відходів галузі (гною та } \\
\text { пташиного посліду) через брак коштів. } \\
\text { 5. Високі витрати на енергетичні ресурси. }\end{array}$ \\
\hline
\end{tabular}

Джерело: узагальнено автором 
Проведений SWOT-аналіз ліг в основу розробки стратегічних планів розвитку виробництва біопалив із біоенергетичного потенціалу агробіомаси сільськогосподарських підприємств, що відображено у SWOT-матриці (рис. 2).

\begin{tabular}{|c|c|c|}
\hline $\begin{array}{r}\text { Зовнішнє } \\
\text { середовище }\end{array}$ & $\begin{array}{c}\text { Можливості: } \\
\text { 1. Вдосконалення державної підтримки } \\
\text { виробництва біопалив } \\
\text { сільськогосподарськими підприємствами. } \\
\text { 2. Наявність науково-дослідних установ та } \\
\text { 3ВО, які займаються питанням } \\
\text { біовиробництва. } \\
\text { 3. Співпраця з міжнародними } \\
\text { фінансовими організаціями. }\end{array}$ & $\begin{array}{c}\text { Загрози: } \\
\text { 1.Відсутність стратегії розвитку } \\
\text { виробництва біопалив, нестабільний } \\
\text { попит на біопаливо. } \\
\text { 2.Проблеми із забезпечення } \\
\text { вітчизняних виробників біопалив } \\
\text { сировиною через iĭ значний експорт. } \\
\text { 3. Висока вартість обладнання для } \\
\text { виробництв біопалив. }\end{array}$ \\
\hline $\begin{array}{c}\text { Сильні сторони } \\
\text { 1. Наявність потенціалу } \\
\text { енергетичних культур та } \\
\text { відходів для } \\
\text { біовиробництва. } \\
\text { 2. Прибутковість більшості } \\
\text { сільськогосподарських } \\
\text { підприємств. } \\
\text { 3. Наявність потенціалу } \\
\text { органічних відходів як } \\
\text { сировини для виробництва } \\
\text { біопалив. }\end{array}$ & $\begin{array}{c}\text { Організація підприємствами } \\
\text { виробництва усіх видів біопалив (рідкі, } \\
\text { тверді, газоподібні), енергетична } \\
\text { автономізація: } \\
\text { 1. Використання державної підтримки } \\
\text { виробництва біопалив } \\
\text { сільськогосподарськими підприємствами } \\
\text { (в разі розробки дієвого механізму). } \\
2 \text { Співпраця з міжнародними } \\
\text { організаціями щодо отримання кредитів } \\
\text { на пільгових умовах. } \\
\text { 3. Організація виробництва твердих } \\
\text { біопалив, біодизелю, біогазу на } \\
\text { підприємствах. }\end{array}$ & $\begin{array}{c}\text { Нарошування біоенергетичного } \\
\text { потенціалу екстенсивним } \\
\text { шляхом, реалізація } \\
\text { біоенергетичних культур } \\
\text { вітчизняним } \\
\text { виробникам біопалив: } \\
\text { 1. Збільшення площ посіву } \\
\text { енергетичних культур. } \\
\text { 2. Налагодження зв’язків із } \\
\text { підприємствами-виробниками } \\
\text { біопалив щодо постачання їм } \\
\text { сировини для виробництва } \\
\text { біопалив (енергетичних культур). }\end{array}$ \\
\hline $\begin{array}{c}\text { Слабкі сторони: } \\
\text { 1. Нераціональне } \\
\text { використання відходів } \\
\text { рослинництва і побічної } \\
\text { продукції тваринництва } \\
\text { (гною). } \\
\text { 2. Відсутність досвіду в } \\
\text { організації виробництва } \\
\text { біопалив. } \\
\text { 3. Відсутність або } \\
\text { недостатній розвиток } \\
\text { інноваційної складової у } \\
\text { господарській діяльності. }\end{array}$ & $\begin{array}{c}\text { 3більшення біоенергетичного } \\
\text { потенціалу інтенсивним шляхом, } \\
\text { організація виробництва тих видів } \\
\text { біопалив, для яких біоенергетичний } \\
\text { потенціал є найбільшим: } \\
\text { 1. Співпраця з державними науково- } \\
\text { дослідними установами та 3ВО щодо } \\
\text { вибору сортів і гібридів біоенергетичних } \\
\text { культур, організації раціональних сівозмін } \\
\text { та найбільш ефективних технологій } \\
\text { виробництва біопалив, техніки та } \\
\text { обладнання. } \\
\text { 2. Раціональне використання відходів та } \\
\text { побічної продукції тваринництва (гною) } \\
\text { як сировини для власного виробництва } \\
\text { біопалив. }\end{array}$ & $\begin{array}{c}\text { Підприємства не нарощують } \\
\text { біоенергетичний потенціал, } \\
\text { залишаються виробниками лише } \\
\text { тих енергетичних культур, на які є } \\
\text { попит на вітчизняному та світовому } \\
\text { ринках: } \\
\text { 1. Виробництво лише тих } \\
\text { біоенергетичних культур, на які є } \\
\text { попит на внутрішньому ринку. } \\
\text { 2. Вихід на зовнішні ринки } \\
\text { біоенергетичної сировини - } \\
\text { виробництво біоенергетичних } \\
\text { культур, на які є попит на ринках } \\
\text { Європи і світу для забезпечення } \\
\text { підвищення рентабельності } \\
\text { сільськогосподарської діяльності. }\end{array}$ \\
\hline
\end{tabular}

\section{Puc. 2. Матриця SWOT-аналізу розвитку виробництва біопалив із біоенергетичного потенціалу агробіомаси сільськогосподарських підприсмств}

\section{Джерело: розроблено автором}

Перша стратегія $є$ найбільш оптимістичною, адже передбачає підтримку i розвиток сильних сторін підприємств для реалізації можливостей зовнішнього середовища. Для аграрних підприємств - це організація виробництва різних видів біопалив (рідкі, тверді, газоподібні) за умови активної державної підтримки розвитку галузі. Стратегічні завдання цієї стратегії включають:

1) використання державної підтримки виробництва біопалив аграрними підприємствами (у разі розробки дієвого механізму підтримки: введення дотацій, субсидій, пільгового державного кредитування); 
2) співпрацю із міжнародними фінансовими організаціями щодо отримання кредитів на пільгових умовах (при умові полегшення доступу до них);

3) організація виробництва усього спектру біопалив: твердих біопалив, біодизелю, біогазу на сільськогосподарських підприємствах та забезпечення їх повної енергетичної автономії, реалізація надлишків на внутрішньому i зовнішньому ринках.

Друга стратегія передбачає боротьбу із загрозами зовнішнього середовища за допомогою використання внутрішніх резервів. Для сільськогосподарських підприємств України - це нарощування біоенергетичного потенціалу екстенсивним шляхом, реалізація біоенергетичних культур вітчизняним підприємствам із біовиробництва, яка передбачатиме:

1) збільшення площ посіву енергетичних культур для нарощування сировинної бази;

2) налагодження зв'язків із підприємствами-виробниками біопалив щодо постачання їм сировини для виробництва біопалив (енергетичних культур).

Третя стратегія - дії підприємств, спрямовані на використання можливостей зовнішнього середовища для подолання слабких сторін його внутрішнього потенціалу. Для аграрних підприємств - це збільшення біоенергетичного потенціалу інтенсивним шляхом, організація виробництва тих видів біопалив, для яких біоенергетичний потенціал $є$ найбільшим.

Вона передбачає наступні стратегічні завдання:

1) співпраця з державними науково-дослідними установами та ЗВО:

- щодо вибору сортів і гібридів біоенергетичних культур, що сприятиме збільшенню біоенергетичного потенціалу підприємств;

- щодо вибору найбільш ефективних технологій виробництва біопалив, техніки та обладнання для забезпечення економічно ефективного біовиробництва;

- щодо складання бізнес-плану виробництва біопалив під конкретні умови замовника.

2) раціональне використання відходів та побічної продукції тваринництва (гною) підприємств, як сировини для виробництва біопалив у межах підприємств;

3) організація раціональних сівозмін, де правильне чергування біоенергетичних культур дозволить збільшувати потенційну урожайність i валові збори та збереження родючості грунтів.

Четверта стратегія дає змогу підприємствам зміцнити свій потенціал і зменшити вплив можливих загроз зовнішнього середовища. Цей варіант $\epsilon$ найбільш песимістичним i використовуватиметься у разі відсутності стратегічного розвитку галузі біовиробництва на рівні держави, зменшення державної підтримки біовиробництва, скорочення попиту на біопаливо. Стратегія передбачатиме, що підприємства не нарощуватимуть біоенергетичний потенціал, а залишатимуться виробниками лише тих енергетичних культур, які мають великий попит на вітчизняному та світовому ринку. Власне виробництво біопалив на підприємствах не передбачається. 
Стратегічні завдання:

- виробництво біоенергетичних культур, які користуються попитом на внутрішньому ринку, і постачання іiі як сировини вітчизняним підприємствам;

- вихід на зовнішні ринки біоенергетичної сировини - виробництво біоенергетичних культур, які мають значний попит на світових ринках.

Висновки. Аграрний сектор України $є$ потужним джерелом біоенергетичної сировини: сільськогосподарських культур, які можна використати на виробництво біопалив та органічних відходів рослинництва i тваринництва. Важливим стратегічним завданням сьогодні $\epsilon$ подальший розвиток біоенергетичного потенціалу сільськогосподарських підприємств та організація останніми виробництва біопалив та біоенергії.

Проведений SWOT-аналіз розвитку виробництва біопалив із біоенергетичного потенціалу агробіомаси показав, що сценарії можуть бути як оптимістичними (розвиток біоенергетичного потенціалу інтенсивним шляхом, організація виробництва біопалив сільськогосподарськими підприємствами, енергетична автономізація), так і песимістичними (аграрні підприємства залишаються лише виробниками сировини для виробництва біопалив, яка далі реалізується в країни Свропи та світу). Від урядових програм стимулювання галузі, стану популяризації виробництва біопалив, інвестиційного клімату у сфері біоенергетики залежатиме, яким шляхом піде наша держава.

\section{Список використаних джерел}

1. Honcharuk I., Babyna O. Dominant trends of innovation and investment activities in the development of alternative energy sources. Wschodnioeuropejskie Czasopismo Naukowe (East European Scientific Journal). 2020. № 2 (54). P. 6-12.

2. Honcharuk T.V. Strategic potential of biomass in Ukraine - guarantee of the state's economic development. Економіка, фінанси, менеджмент: актуальні питання науки і практики. 2017. № 8 (24). С. 36-44.

3. Kaletnik G., Lutkovska S. Innovative Environmental Strategy for Sustainable Development European Journal of Sustainable Development. 2020. Vol. 9, № 2. P. 89-98. DOI: https://doi.org/10.14207/ejsd.2020.v9n2p89.

4. Pryshliak N., Lutsiak V., Tokarchuk D., Semchuk I. The Empirical research of the potential, awareness and current state of agricultural waste use to ensure energy autonomy of agricultural enterprises of Ukraine. Journal of Environmental Management and Tourism. 2020. Vol. 11, № 7. P. 1634-1648. DOI: https://doi.org/10.14505/jemt.v11.7(47).04.

5. Гелетуха Г. Аналіз концепції «зеленого» енергетичного переходу України до 2050 р. Біоенергетика. 2020. № 1 (15). С. 38-39.

6. Державна служба статистики України: веб-сайт. URL: www.ukrstat.gov.ua (дата звернення: 10.02.2021).

7. Ігнатенко О.П. Біоенергетичний потенціал України та регіональні особливості. Екологічний вісник. 2017. № 3. С. 28-29.

8. Калетнік Г.М. Диверсифікація розвитку виробництва біопалив - основа забезпечення продовольчої, енергетичної, економічної та екологічної безпеки 
України. Вісник аграрної науки. 2018. № 11. С. 169-176. DOI: https://doi.org/10.31073/agrovisnyk201811-21.

9. Носонова Л.В. Застосування SWOT-аналізу для визначення конкурентоспроможності АТ «Сумський завод «Насосенергомаш». Глобальні та національні проблеми економіки. 2015. № 4. С. 506-512.

10. Паламаренко Я.В. Сучасний стан та перспективи розвитку біогазової галузі України. Інвестищї: практика та досвід. 2019. № 21. С. 54-62. DOI: $10.32702 / 2306-6814.2019 .21 .54$.

11. Пришляк Н.В., Токарчук Д.М., Паламаренко Я.В. Забезпечення енергетичної та екологічної безпеки держави за рахунок біопалива 3 біоенергетичних культур і відходів. Вінниця: ТОВ «Консоль», 2019. 336 с.

12. Скорук О.П., Токарчук Д.М. Економічна ефективність виробництва i споживання біогазу: світовий і український досвід. Збірник наукових прачь Таврійського державного агротехнологічного університету. Серія: Економічні науки. 2012. № 2 (18), Т. 5. С. 289-298.

13. Токарчук Д.М. Управління ефективним використанням сільськогосподарських відходів для виробництва біогазу. Облік і фінанси. 2018. № 3 (81). C. 133-139.

14. Фурман I.B., Токарчук Д.М. Продовольча безпека та економічні засади виробництва біопалива. Економічний аналіз. 2018. № 1, Т. 28. С. 168-174.

\section{References}

1. Honcharuk, I., \& Babyna, O. (2020). Dominant trends of innovation and investment activities in the development of alternative energy sources Wschodnioeuropejskie Czasopismo Naukowe (East European Scientific Journal), 2 (54), 6-12 [in English].

2. Honcharuk, T.V. (2017). Strategic potential of biomass in Ukraine guarantee of the state's economic development. Ekonomika, finansy, menedzhment: aktualni pytannia nauky i praktyky - Economics, finance, management: topical issues of science and practical activity, 8, 24, 36-44 [in English].

3. Kaletnik, G., \& Lutkovska, S. (2020). Innovative Environmental Strategy for Sustainable Development. European Journal of Sustainable Development, 9, 2, 89-98. DOI: https://doi.org/10.14207/ejsd.2020.v9n2p89 [in English].

4. Pryshliak, N., Lutsiak, V., Tokarchuk, D., \& Semchuk, I. (2020). The empirical research of the potential, awareness and current state of agricultural waste use to ensure energy autonomy of agricultural enterprises of Ukraine. Journal of Environmental Management and Tourism, 11 (7), 1634-1648. DOI: https://doi.org/10.14505/jemt.v11.7(47).04 [in English].

5. Heletukha, H. (2020). Analiz kontseptsii «zelenoho» enerhetychnoho perekhodu Ukrainy do $2050 \mathrm{r}$. [Analysis of the concept of «green» energy transition of Ukraine until 2050]. Bioenerhetyka - Bioenergy, 1 (15), 38-39 [in Ukrainian].

6. Sait Derzhavnoi sluzhby statystyky Ukrainy [Site of the State statistics service of Ukraine]. ukrstat.gov.ua. Retrieved from: www.ukrstat.gov.ua [in Ukrainian]. 
7. Ihnatenko, O.P. (2017). Bioenerhetychnyi potentsial Ukrainy ta rehionalni osoblyvosti [Bioenergy potential of Ukraine and regional features]. Ekolohichnyi visnyk - Ecological Bulletin, 3, 28-29 [in Ukrainian].

8. Kaletnik, G.M. (2018). Dyversyfikatsiia rozvytku vyrobnytstva biopalyv osnova zabezpechennia prodovolchoi, enerhetychnoi, ekonomichnoi ta ekolohichnoi bezpeky Ukrainy [Diversification of biofuel production development is the basis for ensuring food, energy, economic and environmental security of Ukraine]. Visnyk ahrarnoi nauky - Bulletin of Agricultural Science, 11, 169-176. DOI: https://doi.org/10.31073/agrovisnyk201811-21[in Ukrainian].

9. Nosonova, L.V. (2015). Zastosuvannia SWOT-analizu dlia vyznachennia konkurentospromozhnosti AT «Sumskyi zavod «Nasosenerhomash» [Application of SWOT-analysis to determine the competitiveness of JSC «Sumy plant» Nasosenergomash»]. Hlobalni ta natsionalni problemy ekonomiky - Global and national economic problems, 4, 506-512 [in Ukrainian].

10. Palamarenko, Ya.V. (2019). Suchasnyi stan ta perspektyvy rozvytku biohazovoi haluzi Ukrainy [Current state and prospects of development of the biogas industry of Ukraine]. Investytsii: praktyka ta dosvid - Investments: practice and experience, 21, 54-62. DOI: 10.32702/2306-6814.2019.21.54 [in Ukrainian].

11. Pryshliak, N.V., Tokarchuk, D.M., \& Palamarenko, Ya.V. (2018). Zabezpechennia enerhetychnoi ta ekolohichnoi bezpeky derzhavy za rakhunok biopalyva $z$ bioenerhetychnykh kultur $i$ vidkhodiv [Ensuring energy and environmental security of the state through biofuels from bioenergy crops and waste]. Vinnytsia: TOV «Konsol» [in Ukrainian].

12. Skoruk, O.P., \& Tokarchuk, D.M. (2012). Ekonomichna efektyvnist vyrobnytstva i spozhyvannia biohazu: svitovyi i ukrainskyi dosvid [Economic efficiency of biogas production and consumption: world and Ukrainian experience]. Zbirnyk naukovykh prats Tavriiskoho derzhavnoho ahrotekhnolohichnoho universytetu. Seriia: Ekonomichni nauky - Collection of scientific works of Tavriya State Agrotechnological University. Series: Economic Sciences, 2 (18), 5, 289-298 [in Ukrainian].

13. Tokarchuk, D.M. (2018). Upravlinnia efektyvnym vykorystanniam silskohospodarskykh vidkhodiv dlia vyrobnytstva biohazu [Management of efficient use of agricultural waste for biogas production]. Oblik $i$ finansy - Accounting and finance, 3, 81, 133-139 [in Ukrainian].

14. Furman, I.V., \& Tokarchuk, D.M. (2018). Prodovolcha bezpeka ta ekonomichni zasady vyrobnytstva biopalyva [Food security and economic principles of biofuel production]. Ekonomichnyi analiz - Economic analysis, 1, 28, 168-174 [in Ukrainian].

\section{Відомості про автора}

ТОКАРЧУК Діна Миколаївна - кандидат економічних наук, доцент кафедри адміністративного менеджменту та альтернативних джерел енергії, Вінницький національний аграрний університет (21008, м. Вінниця, вул. Сонячна, 3, e-mail: tokarchyk_dina@ukr.net).

TOKARCHUK Dina - Candidate of Economic Sciences, Associate Professor 
of the Department of the Administrative Management and Alternative Energy Resources, Vinnytsia National Agrarian University (21008, Vinnytsia, 3, Soniachna Str., e-mail: tokarchyk_dina@ukr.net).

ТОКАРЧУК Дина Николаевна - кандидат экономических наук, доцент кафедры административного менеджмента и альтернативных источников энергии, Винницкий национальный аграрный университет (21008, г. Винница, ул. Солнечная, 3, e-mail: tokarchyk_dina@ukr.net).

УДК 330.1; 620.92

DOI: 10.37128/2411-4413-2021-3-2

БІОПАЛИВО 3 ВОДОРОСТЕЙ ЯК НАПРЯМ

РОЗВИТКУ «ЗЕЛЕНОЇ» ЕКОНОМІКИ: СУЧАСНИЙ СТАН ТА ПЕРСПЕКТИВИ
ШЕВЧУК Г.В., кандидат економічних наук, старший викладач кафедри адміністративного менеджнменту та альтернативних джерел енергії, Вінницький національний аграрний університет (м. Вінниця)

У статті розглянуто екологічні аспекти впливу традииійних джерел енергії на навколишнє середовище. Обтрунтовано причини явища, коли потреби в енергетиці та проблеми в екології ведуть до пошуку альтернативних видів палива. Проведено порівняльний аналіз структури загального постачання традииійних та альтернативних джерел енергіï. Проаналізовано сучасний стан виробництва, використання традиційних палив та перспективу виробництва біологічних видів палив в Україні. Відображено прогнозовану структуру використання традииійних та альтернативних видів палив згідно 3 Енергетичною стратегією України до 2035 року «Безпека, енергоефективність, конкурентоспроможність».

Наведено класифікацію біопалив залежно від сировини: першого, другого та третього покоління. На відміну від біопалив з таких культур, як иукровий очерет і кукурудза (біопаливо першого покоління), а також із відходів тваринного і рослинного походження (другого покоління), паливо, яке отримане з водоростей (біопаливо третього покоління), має безліч переваг. Зокрема, це більший потенщіал виробництва біопалива порівняно $з$ попередніми технологіями: різноманітність можливих видів палива (біодизель, біоетанол, біобутанол, біогаз і навіть реактивне паливо); гнучкі технології виробництва. Досліджено технології вирощування водоростей: у відкритих водоймах або у більи досконалих закритих ставках та біореакторах. Обтрунтовано, щуо найчастіше водорості використовують для виробниитва біодизеля; зроблено порівняння різних технологій його отримання. Проаналізовано зарубіжний досвід виробництва біопалив з водоростей та застосування його різними автомобільними компаніями $i$ підприємствами, а також перспективи виробництва біопалив з водоростей на території України. Не беручи до уваги перспективи виробництва біопалив третього покоління, вважаємо, що питання дослідження залишається недостатньо висвітленим науковиями, а вітчизняним виробникам не вистачає базових знань.

Ключові слова: традиційні джерела енергії, відновлювані джерела енергії, біопаливо, біомаса, мікроводорості, «зелена» економіка.

Табл.: 3. Рис.: 3. Літ.: 19. 